\title{
Fractionation of Hepatic Nonparenchymal Cells
}

\author{
John M. Graham, Ph.D. \\ School of Biomolecular Sciences, Liverpool John Moores University, Office address: \\ 34, Meadway, Upton, Wirral CH49 6JQ \\ E-mail: john@jgrescon.fsbusiness.co.uk
}

Received March 7, 2002; Accepted March 27, 2002; Published May 16, 2002

The majority of parenchymal cells from mammalian liver cells can be removed by very low speed centrifugation $(50 \mathrm{~g})$ but a simple low-density barrier $(1.096 \mathrm{~g} / \mathrm{ml})$ is required to remove the remaining parenchymal cells from the $50-g$ supernatant which contains all of the lower density nonparenchymal cells. Continuous gradients of Nycodenz ${ }^{\circledR}$ can provide satisfactory resolution of Kupffer, stellate, and endothelial cells on an analytical basis but the separation of different cell types is not sufficient preparatively. Flotation through a low-density iodixanol barrier can, however, provide a satisfactory enrichment of the least dense nonparenchymal cell - the stellate cells.

KEY WORDS: liver cells, hepatocytes, parenchymal cells, nonparenchymal cells, stellate cells, Kupffer cells, OptiPrep ${ }^{\mathrm{TM}}$, iodixanol, density barrier

DOMAINS: cell biology, immunology, endocrinology, clinical medicine, medical research, methods and protocols

METHOD TYPE: extraction, isolation, purification and separation

SUB METHOD TYPE: centrifugation

\section{INTRODUCTION}

The fractionation of hepatic nonparenchymal (sinusoidal) cells (Kupffer cells, stellate cells, endothelial cells, etc.) on continuous metrizamide[1] and Nycodenz ${ }^{\circledR}$ gradients[2] has shown that the overlap in banding densities of these cells makes these gradients generally unsatisfactory as a stand-alone procedure to isolate the various cell populations.

Discontinuous gradients of iodinated media are widely used to provide a means of removing residual erythrocytes and parenchymal cell debris from nonparenchymal cell preparations and to prepare a stellate cell-rich fraction. 


\section{Preparation of Nonparenchymal Cells}

Parenchymal cells are routinely prepared by collagenase digestion of the liver using a tissue perfusion system. These cells are then separated from the nonparenchymal cells by differential pelleting at $50 \mathrm{~g}$ for $1-4 \mathrm{~min}$. Although the nonparenchymal cells can be isolated from the $50-\mathrm{g}$ supernatant, the yields are usually low. The most widely used procedure is to perfuse the liver with a mixture of collagenase and Pronase or endotoxin to destroy the parenchymal cells selectively (see Refs. 1 and 2 for details).

\section{Stellate Cells}

These are the least dense of the nonparenchymal cells and can be floated effectively away from the rest of the cells. The low-density fraction may contain almost $80 \%$ stellate cells[2]. The actual density of the low-density layer used by different workers varies somewhat and some of these variations are presented in the Notes section

The following methods are adapted from Bøyum et al.[1] and from Brouwer et a.1[2]. The advantage of using OptiPrep ${ }^{\mathrm{TM}}$ rather than $\mathrm{Nycodenz}^{\circledR}$ is that the density solutions can be made up by dilution of OptiPrep ${ }^{\mathrm{TM}}$ directly with Gey's Balanced Salt Solution (GBSS), while Nycodenz ${ }^{\circledR}$ must be diluted with GBSS minus the $\mathrm{NaCl}$ to keep the osmolality below 300 mOsm.

\section{MATERIALS AND EQUIPMENT}

- Gey's Balanced Salt Solution (GBSS): 7.0 g NaCl, 0.37 g KCl, 70 mg MgSO4.7H2O, $150 \mathrm{mg}$ Na2HPO4.2H2O, $220 \mathrm{mg} \mathrm{CaCl} 2.2 \mathrm{H} 2 \mathrm{O}, 2.27 \mathrm{~g} \mathrm{NaHCO} 3,30 \mathrm{mg} \mathrm{KH} 2 \mathrm{PO} 4,210$ $\mathrm{mg} \mathrm{MgCl} 2.6 \mathrm{H} 2 \mathrm{O}, 1.0 \mathrm{~g}$ glucose dissolved in 11 of water, gassed with 5\% CO2/air; the $\mathrm{pH}$ should be 7.4

- $\quad \operatorname{OptiPrep}^{\mathrm{TM}}(60 \% \mathrm{w} / \mathrm{v}$, iodixanol $)$

- $40 \%(\mathrm{w} / \mathrm{v})$ Iodixanol Working Solution (WS): mix 4 vol of OptiPrep ${ }^{\mathrm{TM}}$ and 2 vol of GBSS

- Plastic conical centrifuge tubes $(50 \mathrm{ml})$

- Plastic Pasteur pipette for overlayering

- Low-speed (temperature-controlled) centrifuge with swinging-bucket rotor

\section{METHODS}

\section{Preparation of Nonparenchymal Cells}

1. Suspend the crude nonparenchymal cells in approx. $10 \mathrm{ml}$ of GBSS $\left(1-4 \times 10^{8}\right.$ cells $)$.

2. Add WS to the cell suspension so that the final concentration of iodixanol is $17 \%(\mathrm{w} / \mathrm{v})$ iodixanol solution $(\rho=1.096 \mathrm{~g} / \mathrm{ml})$.

3. Mix thoroughly but gently.

4. Layer approx. $2 \mathrm{ml}$ of GBSS on top and centrifuge at $400 \mathrm{~g}$ for $15 \mathrm{~min}$. at $20^{\circ} \mathrm{C}$.

5. Allow the rotor to decelerate without the brake.

6. Collect the cells, which band at the interface between the GBSS and the $17 \%$ iodixanol. 


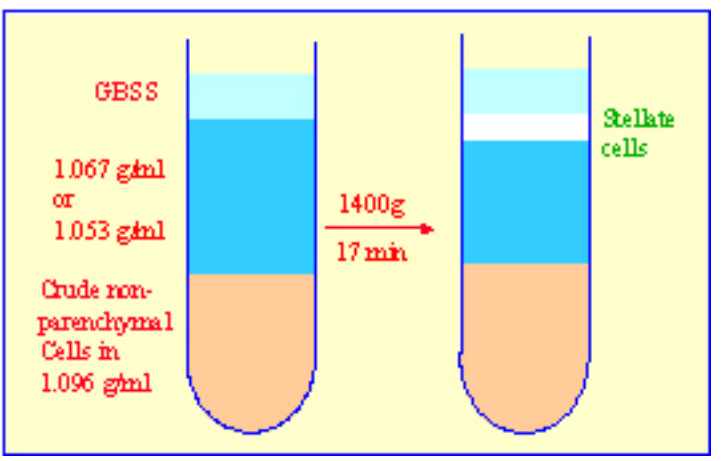

FIGURE 1. Isolation of hepatic stellate cells by flotation. GBSS = Gey’s Balanced Salt Solution.

\section{STELLATE CELLS}

1. Add WS to the cell suspension as described is steps $1-3$ above.

2. Dilute W with GBSS to produce a solution containing $11.5 \%(\mathrm{w} / \mathrm{v})$ iodixanol (see Note 1 ).

3. Layer $5 \mathrm{ml}$ of this solution over the same volume of cell suspension (in $17 \%$ iodixanol); then layer $2 \mathrm{ml}$ of GBSS on top (see Note 2).

4. Centrifuge at $1400 \mathrm{~g}$ for $17 \mathrm{~min}$. at $20^{\circ} \mathrm{C}$; allow the rotor to decelerate without the brake.

5. Collect the cells, which band at the interface between the GBSS and the $11.5 \%$ iodixanol (see Fig. 1).

\section{NOTES}

1. This concentration of iodinated density gradient medium is equivalent to approx $1.067 \mathrm{~g} / \mathrm{ml}$ and has been used both with $\operatorname{Nycodenz}^{\circledR}[1,2]$ and iodixanol[3,4]. A lower-density concentration $(1.053 \mathrm{~g} / \mathrm{ml})$ was used by Cassiman et al.[5]. This is equivalent to approx. $9 \%$ $(\mathrm{w} / \mathrm{v})$ iodixanol.

2. In the method as described by Brouwer et al.[2], the cell suspension was placed in the top layer $(\rho=1.067 \mathrm{~g} / \mathrm{ml})$ rather than the bottom layer $(\rho=1.096 \mathrm{~g} / \mathrm{ml})$ and this is an alternative strategy.

\section{ACKNOWLEDGEMENTS}

The author and TheScientificWorld wish to thank Axis-Shield PoC, AS, Oslo, Norway for their kind permission to adapt OptiPrep ${ }^{\mathrm{TM}}$ Application Sheet C24 in the preparation of this Protocol Article.

\section{REFERENCES}

1. Bøyum, A., Berg, T., and Blomhoff, R. (1983) Fractionation of mammalian cells. In Iodinated Density Gradient Media - A Practical Approach. Rickwood, D., Ed. IRL Press at Oxford University Press, Oxford, U.K. pp. 147-171.

2. Brouwer, A., Hendricks, H.F.J., Ford, T., and Knook, D.L. (1991) Centrifugation separations of mammalian cells. In Preparative Centrifugation - A Practical Approach. Rickwood, D., Ed. IRL Press at Oxford University Press, Oxford, U.K. pp. 271-314. 
3. Elsharkawy, A.M., Wright, M.C., Hay, R.T., Arthur, M.J.P., Hughes, T., Bahr, M.J., Degitz, K., and Mann, D.A. (1999) Persistent activation of nuclear factor- $\mathrm{KB}$ in cultured rat hepatic stellate cells involves the induction of potentially novel Rel-like factors and prolonged changes in the expression of IкB proteins. Hepatology 30, 761-769.

4. Trim, J.E., Samra, S.K., Arthur, M.J.P., Wright, M.C., McAulay, M., Beri, R., and Mann, D.A. (2000) Upstream tissue inhibitor of metalloproteinases-1 (TIMP-1) element-1, a novel and essential regulatory DNA motif in the human TIMP-1 gene promoter, directly interacts with a 30-kDa nuclear protein. 275, 66576663.

5. Cassiman, D., van Pelt, J., De Vos, R., Van Lommel, F., Desmet, V., Yap, S.-H., and Roskams, T. (1999) Synaptophysin: a novel marker for human and rat hepatic stellate cells. Am. J. Pathol. 155, 1831-1839.

This article should be referenced as follows:

Graham, J.M. (2002) Fractionation of hepatic nonparenchymal cells. TheScientificWorldJOURNAL 2, 1347-1350. 


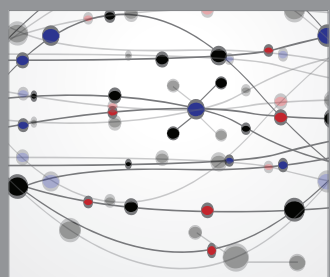

The Scientific World Journal
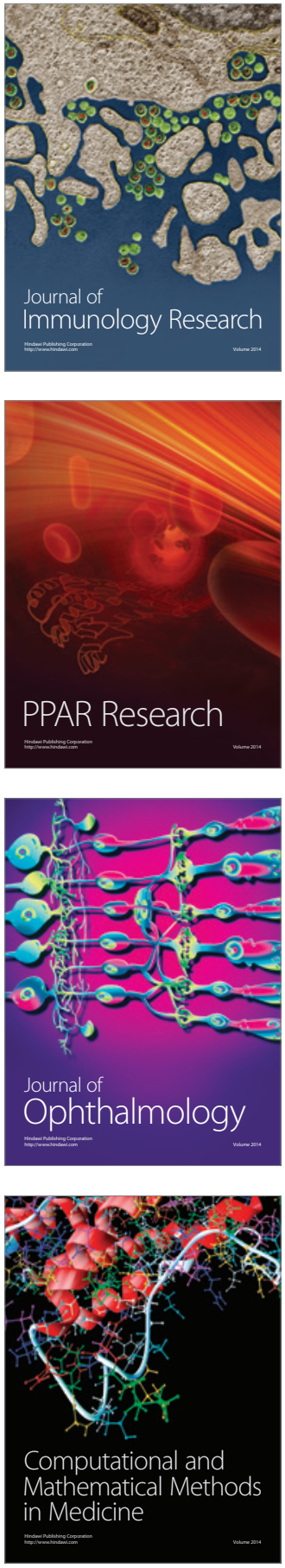

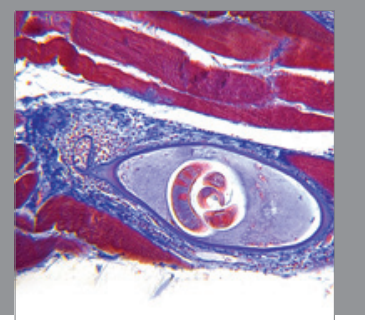

Gastroenterology

Research and Practice
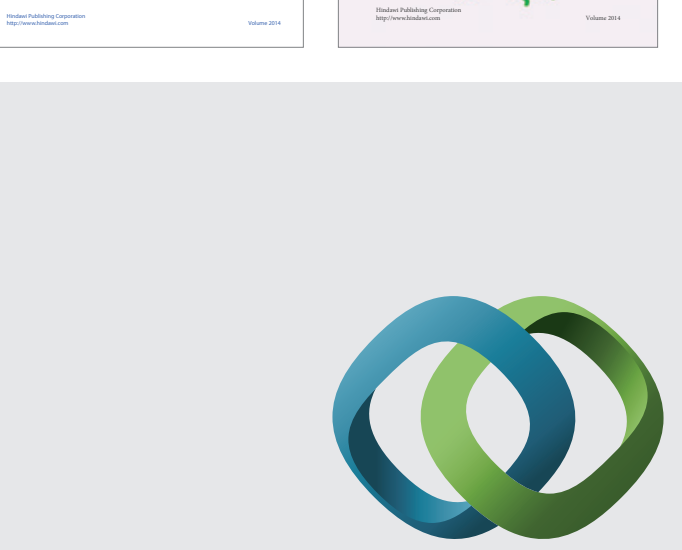

\section{Hindawi}

Submit your manuscripts at

http://www.hindawi.com
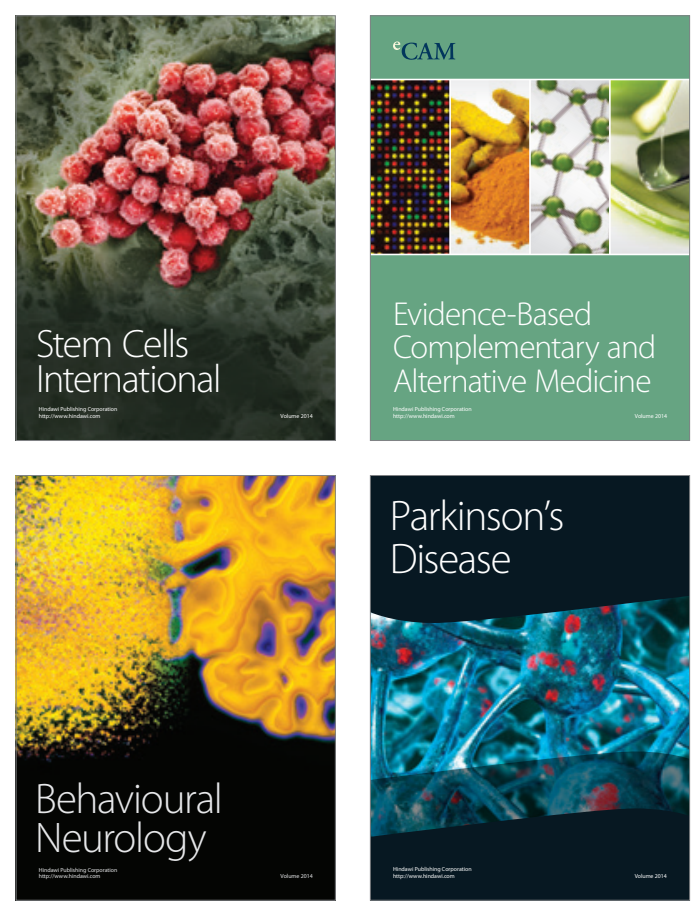

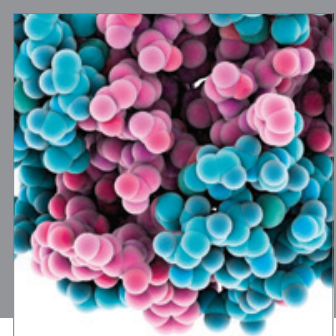

Journal of
Diabetes Research

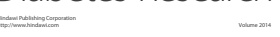

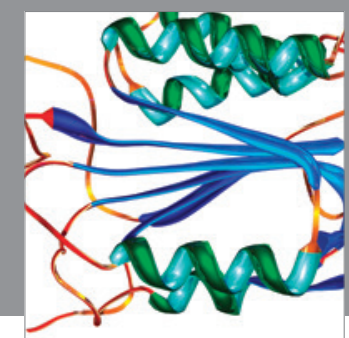

Disease Markers
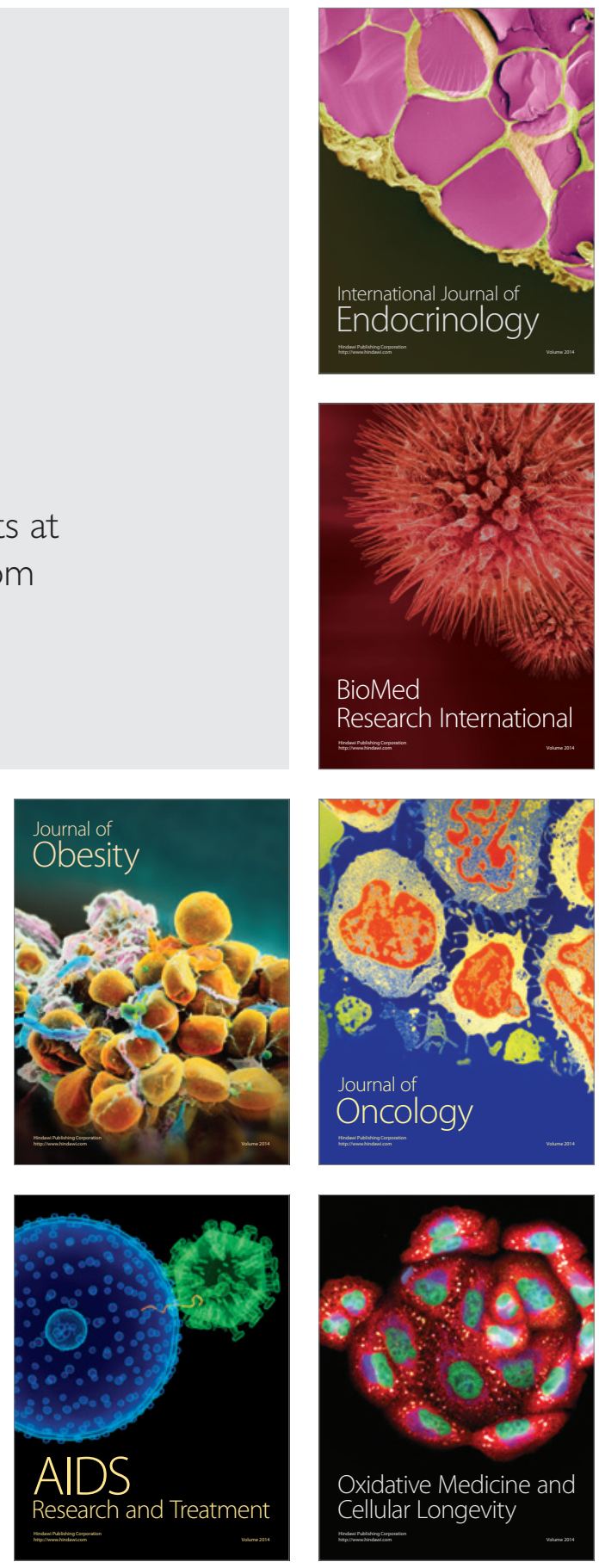